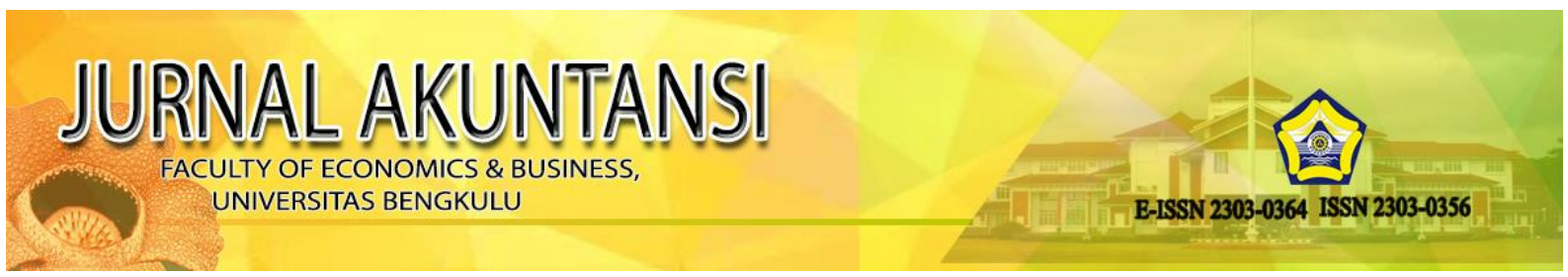

Jurnal Akuntansi

Vol. 9, No.2 2019

DOI: https://doi.org/10.33369/i.akuntansi.9.2.97-110

Hal : 97-110

\title{
ANALISIS PERBANDINGAN GOOD CORPORATE GOVERNANCE BAZNAS DAN LAZNAS
}

\section{Compare Analysis Good Corporate Governance of The Baznas and The Laznas}

\author{
Sri Wahjuni latifah" ${ }^{1)}$, Siska Aprilia' ${ }^{2)}$, Dhaniel Syam ${ }^{3)}$ \\ Program Studi Akuntansi, Fakultas Ekonomi dan Bisnis, Universitas Muhammadiyah Malang
}

\begin{abstract}
This study aims to compare the good corporate governance of the Baznas and Laznas. The samples used in this study were 18 Institutions. The data are obtained from the annual report for 2016-2017 which is published on the official website of pid.baznas.go.id. The analysis technique with content analysis, then hypothesis testing with the Mann Whitney U Test. Based on the results of the study can conclude that there are differences in the application of good corporate governance at the Baznas with Laznas.
\end{abstract}

Keywords: Baznas, Laznas, Good Corporate Governance.

ABSTRAK

Penelitian ini dilakukan untuk menganalisis perbandingan Good Corporate Governance(GCG) Baznas dan Laznas. Sampel penelitian terdiri dari delapan belas lembaga Baznas dan Laznas di Jawa Timur. Data berupa laporan tahunan 2016-2017 yang diterbitkan pada website pid.baznas.go.id. Analisis data pertama melakukan content analysis. Kemudian dilakukan uji hipotesis dengan Mann Whitney U Test. Hasil penelitian dengan uji Mann Whitney U Test menujukkan adanya perbedaan signifikan pada penerapan GCG Baznas dengan Laznas.

Kata Kunci: Baznas, Laznas, Good Corporate Governance.

Corresponding author: Sri Wahjuni latifah

Email addresses for author: yuni.latifah14@gmail.com, siska.aprillia01@gmail.com,dhaniel@umm.ac.id First submission received: 14 Juni 2019

Revised submission received: 13 Juli 2019

Accepted: 19 Juli 2019 


\section{PENDAHULUAN}

Negara Indonesia memiliki jumlah penduduk muslim terbanyak di dunia. Kondisi ini secara tidak langsung dapat membangun masyarakat Indonesia yang sejahtera melalui pemanfaatan zakat, adapun manfaat dari zakat antara lain meratakan pendapatan masyarakat terutama harta yang berada dilingkungan orang kaya dapat didistribusikan kepada kalangan orang yang lemah ekonomi, mendukung fasilitas-fasilitas dakwah, dan mensejahterakan masyarakat.

Pelaksanaan zakat yang telah berlangsung selama ini di Indonesia dirasakan belum efektif. Berbagai upaya dilakukan untuk mencapai efektifitas pelaksanaan pemanfaatan zakat telah dilakukan oleh pemerintah maupun organisasi-organisasi Isam. Sebagaimana UU Republik Indonesia No: 23 /2011 tentang pengelolaan Zakat menjadi payung hukum yang lebih kuat dalam pengelolaan zakat di Indonesia, meruapakan usaha untuk mendukung adanya fakta bahwa Indonesia merupakan negara dengan penduduk muslim terbesar di dunia, yaitu berjumlah $80 \%$ atau 180 juta penduduk muslim dari sekitar 220 juta penduduk Indonesia (Eri, 2008) mempunyai kewajiban dalam membayar zakat .

Kondisi tersebut yang menjadi potensi bahwa zakat merupakan hal yang dapat berkaitan dengan upaya penghimpunan zakat di Indonesia. Undang-Undang pertama yang dikeluarkan pemerintah Indonesia mengenai pengelolaan zakat yaitu UU Republik Indonesia No: 38 /1999 namun undang-undang tersebut memiliki beberapa kelemahan dari aspek yuridis diantaranya dinilai menghambat perkembangan zakat. Misalkan tidak adanya pemisahan yang jelas fungsi regulasi, fungsi pengawasan, dan fungsi pelaksanaan mengelola zakat. Dengan adanya beberapa kelemahan tersebut, sehingga diperlukan adanya sebuah tata kelola dalam pengelolaan zakat agar meningkatkan kepercayaan masyarakat yang menggunakan badan atau lembaga pengelolaan zakat.

Pemerintah hanya meyediakan pelayanan dan penciptaan suasana yang kondusif dalam pengelolaan zakat tetapi pemerintah tidak menegaskan untuk wajib dalam membayar zakat. Dari aspek sosiologis kelemahan pada pengelolaan zakat meliputi kurangnya kesadaran masyarakat dan pengetahuan masyarakat yang masih rendah. Pengetahuan beberapa masyarakat hanya lebih mengarah pada zakat yang dilakukan pada bulan ramadhan atau zakat fitrah, sedangkan mengenai zakat harta masih minim diketahui oleh kalangan masyarakat luas Indonesia. Kemudian kelemahan kedua seperti konsepsi zakat, masih terlalu sederhana dan tradisional. Sehingga pelaksanaannya cukup di bagikan langsung sendiri pada masyarakat sekitar. Ketiga, kepercayaan muzakki kepada lembaga amil zakat masih rendah, karena masyarakat mengganggap bahwa dalam lingkungan pemerintahan terdapat sistem yang lemah dan tidak transparan merupakan kekhawatiran masyarakat tentang distribusi zakat tidak sesuai sasaran (Ulya, 2015). Dengan adanya beberapa kelemahan tersebut, sehingga diperlukan adanya sebuah tata kelola dalam pengelolaan zakat agar meningkatkan kepercayaan masyarakat yang menggunakan badan atau lembaga pengelolaan zakat. Tata kelola atau good governance merupakan cara melakukan pengelolaan organisasi untuk pengelolaan sumberdaya organisasi secara efisien, efektif, ekonomis ataupun produktif dengan prinsip transparan, akuntabilitas, pertanggungjawaban, independen, dan adil untuk mencapai tujuan organisasi (Syakhroza, 2003).

Penelitian Sjahputra dan Tunggal (2010) menyatakan bahwa Good Corporate Governance(GCG) adalah hukum, peraturan, dan kaidah yang perlu dilakukan untuk meningkatkan performance sehingga bekerja secara efisien, efektif dan mencapai keberlanjutan. Hal ini dapat digambarkan sebagai sistem yang dimana perusahaan diarahkan dan dikendalikan untuk kepentingan pemegang saham dan stakeholders lainnya. GCG adalah cara bagaimana suatu perusahaan dapat diatur. Hal ini dapat digambarkan sebagai sistem yang 
dimana perusahaan diarahkan dan dikendalikan untuk kepentingan pemegang saham dan para stakeholders lainnya.

Perusahaan harus diatur demi kepentingan terbaik para pemangku kepentingannya, dan khususnya dari para pemegang sahamnya (Agyeman et al., 2013). Kemampuan perusahaan dalam menarik investor dapat dilihat dari seberapa efektif praktik tata kelol telah dilakukan serta pengungkapan informasinya, dimana para investor akan merasa terlindungi atas investasi dalam perusahaan tersebut.

GCG yang efektif dapat dilakukan melalui networking yang baik antara lembaga/badan pengelola zakat, pemerintah, dan masyarakat. Dalam UU No. 38 /1999 tentang tata kelola zakat disebutkan bahwa peran serta masyarakat juga diharapkan dapat memberikan kontribusi yang diwujudkan dalam bentuk pemerolehan informasi mengenai tata kelola zakat oleh badan/lembaga amil zakat, untuk memberikan saran atau perrtimbangan kepada badan/lembaga amil zakat, dan masyarakat jika terjadi penyimpangan tata kelola zakat (Anwar, 2012).

Undang-Undang pertama yang dikeluarkan pemerintah Indonesia mengenai pengelolaan zakat yaitu Undang Undang Republik Indonesia Nomor 38 Tahun 1999 namun undang-undang tersebut memiliki beberapa kelemahan dari aspek yuridis diantaranya Undang Undang Republik Indonesia No. 38 Tahun 1999 Tentang Pengelolaan Zakat dinilai berpotensi menghambat perkembangan zakat. Salah satunya adalah tidak adanya pemisahan yang jelas antara fungsi regulasi, pengawasan, dan pelaksanaan dalam mengelola zakat. Dengan adanya beberapa kelemahan tersebut, sehingga diperlukan adanya sebuah tata kelola dalam pengelolaan zakat agar meningkatkan kepercayaan masyarakat yang menggunakan badan atau lembaga pengelolaan zakat. Pemerintah hanya meyediakan pelayanan dan penciptaan suasana yang kondusif dalam pengelolaan zakat tetapi pemerintah tidak menegaskan untuk wajib dalam membayar zakat.

Aspek sosiologis kelemahan yang terdapat pada pengelolaan zakat yaitu kurangnya kesadaran masyarakat dan terbatasnya pengetahuan masyarakat yang berkaitan dengan ibadah zakat. Pengetahuan beberapa masyarakat hanya lebih mengarah pada zakat yang dilakukan pada bulan ramadhan atau zakat fitrah, sedangkan mengenai zakat harta masih minim diketahui oleh kalangan masyarakat luas Indonesia. Kemudian kelemahan kedua seperti konsepsi zakat, yang masih dirasa terlalu sederhana dan tradisional. Sehingga di dalam pelaksanaannya hanya cukup di bagikan langsung sendiri pada lingkungannya atau kepada kyai yang disenangi dalam suatu daerah tersebut. Ketiga, kepercayaan muzakki kepada badan atau lembaga amil zakat masih rendah, karena masyarakat mengganggap bahwa dalam lingkungan pemerintahan terdapat sistem yang lemah dan tidak transparan yang mana terdapat indikasi kekhawatiran dari masyarakat bahwa zakat yang diserahkan tidak sampai kepada yang berhak menerimanya (Ulya, 2015). Dengan adanya beberapa kelemahan tersebut, sehingga diperlukan adanya sebuah tata kelola dalam pengelolaan zakat agar meningkatkan kepercayaan masyarakat yang menggunakan badan atau lembaga pengelolaan zakat.

Tata kelola atau good governance merupakan suatu mekanisme tata kelola organisasi secara baik dalam melakukan pengelolaan sumberdaya organisasi secara efisien, efektif, ekonomis ataupun produktif dengan prinsip-prinsip terbuka, akuntabilitas, pertanggungjawaban, independen, dan adil dalam rangka mencapai tujuan organisasi (Syakhroza, 2003). Sjahputra dan Tunggal (2010) menyatakan bahwa Good Corporate Governance adalah sekumpulan hukum, peraturan, dan kaidah-kaidah yang wajib dipenuhi yang dapat mendorong kinerja sumber-sumber perusahaan bekerja secara efisien, menghasilkan nilai ekonomi jangka panjang yang berkesinambungan bagi para pemegang saham maupun masyarakat sekitar secara keseluruhan. Hal ini dapat digambarkan sebagai sistem yang dimana perusahaan diarahkan dan dikendalikan untuk kepentingan pemegang saham dan pemangku kepentingan lainnya. 
Good Corporate Governance mengacu pada cara bagaimana suatu perusahaan dapat diatur. Hal ini dapat digambarkan sebagai sistem yang dimana perusahaan diarahkan dan dikendalikan untuk kepentingan pemegang saham dan pemangku kepentingan lainnya. Perusahaan harus diatur demi kepentingan terbaik para pemangku kepentingannya, dan khususnya dari para pemegang sahamnya (Agyeman et al., 2013). Kemampuan perusahaan dalam menarik investor dapat dilihat dari seberapa efektif praktik tata kelola perusahaan yang telah dilakukan serta pengungkapan informasinya, dimana para investor akan merasa terlindungi atas investasi dalam perusahaan tersebut. Good corporate governance yang efektif dapat dilakukan melalui kerja sama yang baik antara lembaga/badan pengelola zakat, pemerintah, dan masyarakat. Dalam Undang-Undang No. 38 tahun 1999 tentang tata kelola zakat disebutkan bahwa peran serta masyarakat juga diharapkan dapat memberikan kontribusi yang diwujudkan dalam bentuk pemerolehan informasi mengenai tata kelola zakat yang dikelola oleh badan/lembaga amil zakat, menyampaikan saran dan pendapat kepada badan/lembaga amil zakat, dan masyarakat memberikan laporan atas terjadinya penyimpangan dalam tata kelola zakat (Anwar, 2012).

Penelitian dengan tema Badan Amil Zakat di Malang telah dilakukan oleh Anwar (2012). Hasil penelitian tersebut menemukan tentang model umum telah dilaksanakan dengan baik. Terbukti dari organisasi telah terstruktur dan memuliki pemisahan fungsi dan tugas dengan baik. Terdapat hasil prospektif dalam penentuan mustahiq dan muzakki melalui proses seleksi yang ketat dan di dukung hasil dari survei yang harus dilakukan oleh BAZ dan LAZ sehingga, ketepatan sasaran, ketepatan waktu, ketepatan penggunaan, dan ketepatan jumlah dapat dicapai. Demikian juga penelitian Setia (2018) tentang pengaruh penerapan GCG dan budaya organisasi pengelola zakat terhadap motivasi membayar zakat di DIY.Hasil penelitian tersebut menunjukkan bahwa penerapan GCG dan budaya organisasi berpengaruh positif pada motivasi pembayaran zakat penghasilan. Penelitian perbandingan good corporate governance ini dilakukan pada Baznas (Badan Amil Zakat Nasional) dan Laznas(Lembaga Amil Nasional) yang merupakan organisasi sektor publik yang kegiatan utamanya adalah melakukan peran intermediasi pengelolaan dana zakat, menghimpun dana, mendistribusikan dan memanfaatkan zakat sesuai dengan ketentuan agama.

Penelitian ini dilakukan pada BAZNAS dan LAZNAS di Jawa Timur dengan alasan pada tahun 2017 angka kemiskinan di Jawa Timur mencapai 11,20\% dimana potensi zakat di Jatim sangat besar karena mayoritas masyarakatnya adalah muslim yang memiliki kewajiban untuk berzakat. Sehingga pelaksanaan zakat perlu dilakukan secara efektif dengan tata kelola atau good corporate governance(GCG) yang baik akan mengatasi permasalahan tersebut. Melalui penelitian ini, peneliti berupaya mengurangi atau meminimalisir risiko-risiko yang mungkin dapat terjadi terhadap badan/lembaga amil zakat, muzakki dan mustahiq. Dengan GCG yang baik maka akan meminimalkan risiko ketidakpercayaan stakeholder terhadap badan amil zakat, sedangkan dengan GCG yang buruk akan mempengaruhi kinerja dan menurunkan kepercayaan masyarakat terhadap instansi terkait

\section{KERANGKA TEORITIS DAN HIPOTESIS}

\section{Teori Keagenan (Agency Theory)}

Asumsi yang utama dari teori keagenan bahwa tujuan principal dan tujuan agen yang berbeda dapat memunculkan konflik karena manajer perusahaan cenderung untuk mengejar tujuan pribadinya sendiri, misalnya berusaha untuk memperoleh bonus setinggi mungkin. Manajer cenderung untuk menunjukkan "egoisme" (perilaku yang mengarahkan mereka untuk memaksimalkan kepentingan diri mereka sendiri). Hal ini dapat mengakibatkan kecenderungan manajer untuk memfokuskan pada proyek dan investasi perusahaan yang menghasilkan laba 
yang tinggi dalam jangka pendek daripada memaksimalkan kesejahteraan pemegang saham melalui investasi di proyek-proyek yang menguntungkan dalam jangka panjang.

\section{Good Corporate Governance}

Good Corporate governance adalah seperangkat peraturan yang mengatur hubungan antara pemegang saham, pengurus perusahaan, pihak kreditur, pemerintah, karyawan serta para pemegang kepentingan intern dan ekstern lainnya yang berkaitan dengan hak-hak dan kewajiban mereka (Hery, 2010).

\section{Prinsip Good Corporate Governance}

Menurut BUMN No. 117/MMBU/2002, bahwa dalam penerapan good corporate governance di BUMN dikenal lima prinsip utama. Beberapa komponen utama yang diperlukan dalam Good Corporate governance (GCG) yaitu transparency, accountability, responsibility, independency dan fairness.

\section{Zakat}

Zakat merupakan salah satu rukun Islam yang memiliki dua dimensi yang berbeda namun saling berkaitan, yaitu dimensi vertikal dan dimensi horizontal. Dimensi vertikal memiliki makna berhubungan dengan Allah Swt., dan dimensi horizontal bermakna hubungan dengan manusia. Zakat ditinjau dari segi bahasa memiliki beberapa arti diantaranya, alBarakatu (keberkahan), al-Nama' (pertumbuhan dan perkembangan), al-Thaharatu (kesucian), al-Shalahu (keberesan).

\section{Perumusan Hipotesis}

Forum for Corporate Governance in Indonesia (FCGI) menyebutkan bahwa corporate governance merupakan seperangkat peraturan yang mengatur hubungan antara pemegang saham, pengurus atau pengelola perusahaan yang berkaitan dengan hak dan kewajiban atau pengendalian perusahaan yang tujuannya untuk menciptakan nilai tambah bagi semua pihak yang berkepentingan. Konsep good corporate governance dalam konteks badan/lembaga amil zakat menurut Nasution (2009) adalah sekumpulan dari kesiapan organisasi yang memiliki keselarasan antara tindakan manajemen dalam lembaga pengelola zakat dengan keinginan para stakeholdernya, mendorong lembaga pengelola zakat dalam menggunakan sumber daya secara efektif, dan kepatuhan suatu organisasi dengan peraturan atau prinsip-prinsip syariah yang berlaku.

Penelitian Anwar (2012) yang dilakukan pada Badan/Lembaga Amil Zakat di Malang menghasilkan bahwa tata kelola telah dilakukan dengan baik, yang dibuktikan dengan adanya pemisahan tugas dan tanggung jawab dari organisasi tersebut. Badan Amil Zakat dan Lembaga Amil Zakat merupakan organisasi pengelola zakat yang memiliki peran dan fungsi yaitu mengumpulkan, mendistribusikan, dan mendayagunakan zakat sesuai dengan ketentuan agama. Perbedaan kedua lembaga tersebut terletak pada pembentukannya. Badan Amil Zakat dibentuk oleh lembaga pemerintah, sedangkan Lembaga Amil Zakat dibentuk atas prakarsa masyarakat. Pembentukan organisasi tersebut menimbulkan adanya perbedaan persepsi masyarakat, organisasi pengelola zakat yang dibentuk oleh pemerintah dianggap tidak transparan dan memiliki sistem yang lemah, sehingga masyarakat lebih memilih pada Lembaga Amil Zakat yang dibentuk bukan dari pemerintah, karena masyarakat menganggap dapat dipercaya dan lebih fleksibel mengenai waktu pengumpulannya.

Penerapan GCG di organisasi publik, diharapkan dapat mengembalikan kepercayaan masyarakat, tanggung jawab sosial perusahaan dan etika bisnis. Suatu bisnis tidak hanya dijalankan dengan modal uang, tetapi juga dengan tanggung jawab dan moralitas perusahaan 
terhadap stakeholders dan masyarakat. Good corporate governance dalam suatu organisasi pengelolaan zakat merupakan sesuatu yang sangat penting bagi pembayar zakat untuk memberikan keyakinan bahwa zakat yang mereka bayarkan digunakan secara efesien dan efektif untuk memenuhi kepentingan terbaik (Husein, 2002). Berdasarkan penjelasan tersebut, maka hipotesis yang diajukan:

$\mathrm{H}_{1}$ : Terdapat perbedaan Penerapan good corporate governance pada Baznas berbeda dan Laznas.

\section{METODE PENELITIAN}

Penelitian ini merupakan penelitian komparatif, yaitu penelitian yang membandingkan dua atau lebih objek kalian dalam suatu topik/bidang (Ulum dan Juanda, 2016). Penelitian ini membandingkan good corporate governance atau tata kelola antara Baznas dan Laznas di Jawa Timur. Populasi yang digunakan pada penelitian ini adalah lembaga non-struktural yaitu Badan Amil Zakat Nasional dan Lembaga Amil Zakat Nasional di Jawa Timur. Populasi BAZNAS di Jawa Timur sebanyak 31, sedangkan untuk populasi LAZNAS sebanyak 18. Sampel pada penelitian ini berjumlah sampel(9) sampel Badan Amil Zakat Nasional dan sembilan(9) sampel Lembaga Amil Zakat Nasional. Penentuan sampel pada penelitian ini dilakukan berdasarkan metode purposive sampling. Adapun kriteria yang diajukan dalam penelitian meliputi Badan Amil Zakat dan Lembaga Amil Zakat Nasional skala kabupaten/kota Jawa Timur, Badan Amil Zakat dan Lembaga Amil Zakat Nasional yang mempunyai website resmi, dan Badan/Lembaga Amil Zakat Nasional yang menyantumkan annual report periode 2016-2017 atau laporan informasi dalam website.

Fokus kajian ini adalah good corporate governance. Pengukuran corporate governance dapat dikur melalui Corporate Governance Perception Index (CGPI) yang diterbitkan oleh Indonesian Institute For Corporate Directorship. Adapun rumus indeks good corporate governance yaitu.

CGPI $=\frac{\text { Total item yang diungkapkan oleh perusahaan }}{\text { Total item good corporate governance }} \times 100$

Analisis data dalam penelitian ini adalah menggunakan content analysis dengan menganalisis isi dengan memberikan check list terhadap indikator good corporate governance yang diungkapkan pada official website masing-masing objek. Kemudian dilakukan uji Mann Whitney U Test untuk mengetahui perbedaan dua sampel yang tidak berhubungan atau berpasangan satu sama lain.

\section{HASIL DAN PEMBAHASAN}

Berdasarkan data yang diperoleh dari website resmi BAZNAS, terdapat 31 Badan Amil Zakat Nasional dan 18 Lembaga Amil Zakat Nasional di Jawa Timur. Sesuai dengan kriteria yang telah ditetapkan sebagai sampel yakni mempunyai kelengkapan data yang diperlukan dalam penelitian, maka diperoleh sebanyak sembilan(9) sampel BAZNAS dan sembilan(9) sampel LAZNAS.

Lembaga BAZNAS (Badan Amil Zakat Nasional) merupakan badan resmi dan satusatunya yang dibentuk oleh pemerintah berdasarkan Keputusan Presiden RI No. 8 Tahun 2001 yang memiliki tugas dan fungsi menghimpun dan menyalurkan zakat, infaq, dan sedekah (ZIS) pada tingkat nasional. Sedangkan Lembaga Amil Zakat Nasional (LAZNAS) merupakan 
merupakan lembaga pengelola zakat yang dibentuk oleh swasta atau diluar pemerintah dalam skala nasional.

\section{Analisis Statistik Deskriptif}

Hasil statistik deskriptif yang diperoleh penelitian ini dipaparkan sebagai berikut :

Tabel 1. Statistik Deskriptif Penerapan Lima Prinsip GCG

\begin{tabular}{lrrrrrr}
\hline & N & Minimum & Maximum & Mean & $\begin{array}{c}\text { Std. } \\
\text { Deviation }\end{array}$ & Variance \\
\hline BAZNAS & & & & & & \\
Transparancy & 9 & 7.00 & 12.00 & 9.5556 & 1.42400 & 2.028 \\
Accountability & 9 & .00 & 2.00 & .7778 & .66667 & .444 \\
Responsibility & 9 & 2.00 & 2.00 & 2.0000 & .00000 & .000 \\
Independency & 9 & .00 & 1.00 & .4444 & .42705 & .278 \\
Fairness & 9 & 1.00 & 2.00 & 1.4444 & .52705 & .278 \\
Valid N & 9 & & & & & \\
(listwise) & & & & & & \\
LAZNAS & & & & & & \\
Transparancy & 9 & 5.00 & 10.00 & 7.1111 & 1.36423 & 1.861 \\
Accountability & 9 & .00 & 1.00 & .4444 & .42705 & .278 \\
Responsibility & 9 & 1.00 & 2.00 & 1.5556 & .52705 & .278 \\
Independency & 9 & .00 & 1.00 & .1111 & .33333 & .111 \\
Fairness & 9 & 1.00 & 2.00 & 1.1111 & .33333 & .111 \\
Valid N & 9 & & & & & \\
(listwise) & & & & & & \\
\hline
\end{tabular}

Berdasarkan tabel 1 menunjukkan bahwa penerapan komponen good corporate governance pada BAZNAS dan LAZNAS di Jawa Timur memiliki perbedaan nilai yang signifikan. BAZNAS memiliki nilai rata-rata Transparancy sebesar 9.5556, dengan nilai max sebesar 12.00 dan nilai min sebesar 7.00, pada Responsibility dihasilkan nilai rata-rata sebesar 2.0000 dengan nilai max 2.00 dan nilai min sebesar 2.00, Accountability pada BAZNAS memiliki nilai rata-rata sebesar 0.7778 dengan nilai max sebesar 2.00 dan min sebesar 0.00 , Independency menghasilkan nilai rata-rata sebesar 0.4444 dengan nilai max sebesar 1.00 dan min sebesar 0.00, dan Fairness memiliki nilai rata-rata sebesar 1.4444 dengan nilai max 2.00 dan nilai min sebesar 1.00 .

Sedangkan pada Lembaga Amil Zakat dihasilkan nilai rata-rata pada komponen Transparancy sebesar 7.1111, dengan nilai max sebesar 10.00 dan nilai min sebesar 5.00, Accountability memiliki nilai rata-rata sebesar 0.4444 dengan nilai max sebesar 1.00 dan min sebesar 0.00, pada Responsibility dihasilkan nilai rata-rata sebesar 1.5556 dengan nilai max 2.00 dan nilai min sebesar 1.00, Independency menghasilkan nilai rata-rata sebesar 0.1111 dengan nilai max sebesar 1.00 dan min sebesar 0.00, dan Fairness memiliki nilai rata-rata sebesar 1.1111 dengan nilai max 2.00 dan nilai min sebesar 1.00. 
Secara keseluruhan berikut hasil indeks CGPI:

Tabel 2. Ringkasan CGPI

\begin{tabular}{lclc}
\hline BAZNAS & CGPI & LAZNAS & CGPI \\
\hline BAZNAS Kab. Lumajang & 60,87 & $\begin{array}{l}\text { LAZ Dompet Amanah Umat Sedati } \\
\text { Sidoarjo }\end{array}$ & 47,83 \\
\hline BAZNAS Kab. Ponorogo & 60,87 & LAZ Muhammadiyah Jember & 47,83 \\
\hline BAZNAS Kab. Sidoarjo & 56,52 & LAZ Muhammadiyah Malang & 39,13 \\
\hline BAZNAS Kab. Tulungagung & 69,57 & LAZ Nurul Hayat Surabaya & 60,87 \\
\hline BAZNAS Kota Gresik & 65,22 & LAZ Ummul Quro' Jombang & 52,17 \\
\hline BAZNAS Kota Madiun & 82,61 & LAZ Yatim Mandiri Surabaya & 43,48 \\
\hline BAZNAS Kota Malang & 47,83 & $\begin{array}{l}\text { LAZ Yayasan Amal Sosial Ash } \\
\text { Shohwah Malang }\end{array}$ & 39,13 \\
\hline BAZNAS Kota Pasuruan & 52,17 & LAZ Yayasan Dana Sosial Al Falah & 30,43 \\
\hline BAZNAS Trenggalek & 60,87 & $\begin{array}{l}\text { LAZ Yayasan Lembaga Manajemen } \\
\text { Infaq Mojokerto }\end{array}$ & 43,48 \\
\hline Rata-rata & 61,83 & \multicolumn{2}{c}{ Rata-rata } \\
\hline
\end{tabular}

Tabel 2 menunjukkan bahwa penerapan good corporate governance pada BAZNAS di Jawa Timur rata-rata sebesar 61,83 dengan demikian dapat dikatakan telah menerapkan prinsip GCG secara baik. Sedangkan penerapan good corporate governance pada LAZNAS rata-rata sebesar 44,92 yang menunjukkan bahwa penerapan prinsip GCG masih rendah.

\section{Uji Mann-whitney test}

Digunakan untuk mengetahui perbedaan dua sampel yang tidak berhubungan atau berpasangan satu sama lain. Uji Mann-whitney dapat diketahui memiliki nilai yang signifikan atau tidak dengan membandingkan antara Mann-whitney test yang di hitung dengan Mannwhitney test tabel pada probbilitas tertentu yaitu 0,05 .

Tabel 3. Hasil Uji Rata-Rata

\begin{tabular}{llrrr}
\hline & Variabel & \multicolumn{1}{c}{$\mathrm{N}$} & Mean Rank & Sum of Ranks \\
\hline Indeks & BAZNAS & 9 & 13.22 & 119.00 \\
& LAZNAS & 9 & 5.78 & 52.00 \\
& Total & 18 & & \\
\hline
\end{tabular}

Tabel 3 menunjukkan Mean Rank penerapan lima prinsip good corporate governance pada BAZNAS memiliki penerapan good corporate governance yang lebih tinggi jika dibandingkan dengan LAZNAS. Hal ini dibuktikan dengan jumlah rata-rata yang dimiliki BAZNAS sebesar 13.22, sedangkan Lembaga LAZNAS memiliki nilai rata-rata yang lebih rendah yaitu sebesar 5.78.

\begin{tabular}{lr}
\multicolumn{2}{c}{ Tabel 4. Hasil Uji Mann-whitney test } \\
\hline \multicolumn{2}{c}{ Indeks } \\
\hline Mann-Whitney U & 7.000 \\
Wilcoxon W & 52.000 \\
Z & -2.984 \\
Asymp. Sig. (2-tailed) & .003 \\
Exact Sig. [2*(1-tailed Sig.)] & $.002^{\mathrm{a}}$ \\
\hline
\end{tabular}


Tabel 4 di atas menunjukkan nilai $\mathrm{U}$ sebesar 7 dan nilai $\mathrm{W}$ sebesar 52. Apabila nilai tersebut dikonversikan ke nilai $\mathrm{Z}$ maka besarnya nila $\mathrm{Z}$ hitung adalah -2.984. Nilai Asymp. Sig. (2-tailed) atau P Value sebesar 0.003, lebih kecil dari 0.05. Artinya terdapat perbedaan yang signifikan dalam penerapan good corporate governance pada Baznas dan Laznas. Adanya perbedaan penerapan good corporate governance tersebut disebabkan salah satu komponen GCG yaitu transparansi, telah diterapkan dengan baik oleh Baznas dibandingkan pada Laznas.

\section{Penerapan Good Corporate Governance pada Baznas}

Hasil penelitian yang dilakukan menunjukkan bahwa Badan Amil Zakat Nasional telah menerapkan prinsip good corporate governance, dari kelima prinsip GCG yaitu Transparancy, Accountability, Responsibility, Independent, dan Fairness telah diterapkan dengan baik. Hal ini disebabkan BAZNAS memiliki rata-rata nilai CGPI sebesar 61,83 bahkan ada yang memiliki nilai tinggi sebesar $82,61 \%$ yaitu BAZ Kota Madiun, artinya BAZNAS telah secara baik dalam mengungkapkan informasi mengenai good corporate governance pada laporan keuangan maupun websitenya. Hasil indeks yang tinggi tersebut didorong oleh hasil content analys pada komponen Transparancy, hal ini dibuktikan dengan indeks yang dihasilkan beberapa BAZNAS salah satunya kota Madiun sebesar 52,2 yang artinya pengungkapan informasi mengenai lembaga, kepengurusan, visi, misi, dan kegiatan lembaga tersebut dipublikasikan dalam website maupun annual report. Dengan adanya transparansi yang baik maka para stakeholder yang memiliki kepentingan dapat mengakses informasi sesuai dengan kebutuhannya.

Penerapan good corporate governance pada BAZNAS di tandai dengan adanya transparansi dan akuntabilitas yang baik seperti, mengungkapkan visi, misi, tujuan, maupun penerbitan laporan keuangan BAZNAS. BAZNAS memiliki struktur kepengurusan, pemisahan tugas, dan pertanggungjawaban yang baik. BAZNAS telah menerapkan prinsip transparansi yang ditandai dengan keterbukaan dalam melakukan proses pengambilan keputusan dan keterbukaan dalam mengungkapkan informasi mengenai organisasi seperti menyediakan informasi yang dapat diakses, memadai, jelas dan akurat. Dengan adanya good corporate governance yang baik, secara tidak langsung dapat meningkatkan kepercayaan dan keyakinan masyarakat bahwa zakat yang mereka bayarkan digunakan secara efisien dan efektif oleh organisasi pengelola zakat untuk kepentingan yang terbaik (Husein, 2002).

Hal ini dapat dilihat dari jumlah muzakki yang dimiliki oleh Badan Amil Zakat Nasional di Jawa Timur mencapai kurang lebih 1.000 muzakki. Hasil penelitian ini sesuai dengan penelitian Anwar (2012) bahwa model umum tata kelola pemerintahan telah dijaga dengan baik dalam Badan Amil Zakat kota Malang. Hal ini dapat dibuktikan dari organisasi yang terstruktur, adanya pemisahan tugas dan tanggung jawab.

Penerapan good corporate governance dalam BAZNAS juga telah ditandai dengan adanya komponen independency yang telah dilakukan yaitu RUPS. Rata-rata BAZNAS telah melakukan RUPS minimal satu kali dalam satu periode, hal ini sesuai dengan teori dasar yang digunakan dalam penelitian yaitu teori agensi. Dalam teori agensi dijelaskan bahwa agen diberikan kewenangan untuk mengelola keuangan pihak principal dan harus mampu mempertanggungjawabkan modal tersebut, sehingga dilakukan RUPS agar pihak principal dapat mengendalikan dan mengawasi mengenai modal yang dia berikan. Hal ini dilakukan agar dapat meminimalisir timbulnya ketidakpercayaan pihak principal kepada pihak agen.

BAZNAS juga memiliki akuntabilitas kepada pemerintah serta harus mengawasi Lembaga Amil Zakat (LAZ) untuk menghindari terbentuknya LAZ ilegal dan memastikan bahwa LAZ senantiasa memberikan laporan secara berkala atas laporan keuangan, kegiatan penghimpunan, penya luran, serta pendayagunaan dana zakat yang telah diaudit kepada BAZ. 


\section{Penerapan Good Corporate Governance pada Laznas}

Hasil penelitian yang dilakukan menunjukkan bahwa Laznas telah menerapkan prinsip good corporate governance. Namun dalam penerapan good corporate governance tersebut masih belum seutuhnya prinsip-prinsip good corporate governance diterapkan. Hal ini karena Lembaga Amil Zakat Nasional di hanya memiliki Corporate Governance Perception Index (CGPI) tertinggi sebesar 60,87\% yang dihasilkan dari satu Lembaga Amil Zakat Nasional yaitu LAZ Nurul Hayat Surabaya. Secara rata-rata LAZ memiliki total indeks GCG sebesar 44,92 berarti dibawah 50\% atau dibawah standar yang ditetapkan dalam CGPI.

Hasil indeks tertinggi pada Lembaga Amil Zakat Nurul Hayat Surabaya sebesar 60.87 dan yang paling banyak adalah pada komponen Transparancy yaitu sebesar 43.5. Beradasar content analys ditemukan adanya informasi yang lengkap diungkapkan pada website lembaga maupun annual report pada LAZ Nurul Hayat Surabaya, misalnya mengenai visi lembaga, misi, kondisi keuangan, dan susunan kepengurusan. Sebagai lembaga diluar pemerintah, LAZNAS tidak seutuhnya mendapatkan kontribusi dari pemerintah dan kurang mudahnya untuk medapatkan perizinan. Sehingga LAZNAS menerapkan prinsip mandiri, profesional, amanah, dan memberdayakan yang ditanamkan untuk mencapai tujuannya

Penerapan good corporate governance pada Lembaga Amil Zakat Nasional di Jawa Timur ditandai dengan adanya komponen GCG yang telah diterapkan dengan baik seperti komponen transparansi. Beberapa LAZNAS memiliki transaparansi yang baik dalam mengungkapkan informasi lewat website resminya, namun masih terdapat beberapa lainnya yang tidak mencantumkan informasi-informasi mengenai visi, misi, dan kejadian penting yang menjadi tolak ukur dalam komponen transparansi.

Mengenai akuntabilitas beberapa LAZNAS di Jawa Timur masih kurang menerapkan prinsip tersebut dengan baik, hal ini dikarenakan pada saat melakukan content analys dihasilkan nilai indeks sebesar 0, diantaranya pada LAZ Yayasan Dana Sosial Al Falah dan LAZ Muhammadiyah Malang. Hal ini dikarenakan lembaga tersebut tidak mengungkapkan indikator dari accountability yaitu anggota komite dan reward yang diberikan kepada pengurus.diungkapkan dalam laporan keuangan maupun website LAZNAS.

Independency pada LAZNAS banyak dihasilkan nilai indeks sebesar 0 , hal ini dikarenakan pada saat melakukan content analys beberapa LAZNAS tidak mengungkapkan item dalam komponen Independency yaitu mengenai pelaksanaan RUPS. Pada segi Transparansi LAZNAS sudah menerapkannya dengan baik, namun mengenai komponen good corporate governance yang lainnya masih belum diterapkan secara seutuhnya. Penelitian yang dihasilkan sesuai dengan penelitian Fitrah et al (2017) pada Baitul Mal Aceh bahwa prinsip syariah, amanah, keadilan, dan transparansi telah berjalan dengan baik namun masih terdapat sistem yang kurang memadai sehingga pengelolaan zakat masih kurang efisien.

\section{Perbandingan Penerapan Good Corporate Governance pada Badan Amil Zakat Nasional dan Lembaga Amil Zakat Nasional}

Berdasarkan hasil penelitian yang dilakukan menunjukkan bahwa Badan Amil Zakat Nasional telah menerapkan prinsip good corporate governance dengan baik daripada Lembaga Amil Zakat Nasional. Hal ini dibuktikan melalui hasil statistik deskripsif yang digambarkan bahwa BAZNAS memiliki nilai rata-rata good corporate governance lebih besar dibandingkan dengan nilai rata-rata good corporate governance LAZNAS. Badan Amil Zakat Nasional mengungkapkan komponen GCG dengan nilai rata-rata sebesar 61,83 sedangkan Lembaga Amil Zakat Nasional hanya mengungkapkan komponen GCG dengan nilai rata-rata sebesar 
44,92. Pada hasil statistik tersebut sudah terlihat bahwa terdapat perbedaan penerapan good corporate governance pada Badan Amil Zakat Nasional dan Lembaga Amil Zakat Nasional.

Badan Amil Zakat Nasional di Jawa Timur telah menerapkan prinsip good corporate governance, berdasarkan kelima prinsip GCG yaitu Transparancy, Accountability, Responsibility, Independent, dan Fairness telah diterapkan dengan baik. Hal ini didukung dengan hasil perolehan Corporate Governance Perception Index (CGPI) Badan Amil Zakat Nasional di Jawa Timur yang memiliki nilai indeks GCG tertinggi sebesar 82,61\%. Sedangkan untuk Lembaga Amil Zakat Nasional di Jawa Timur memperoleh indeks GCG tertinggi hanya sebesar $60,87 \%$.

Berdasarkan prinsip Transparancy, informasi penting pada lembaga pengelola zakat juga perlu diketahui oleh publik. BAZNAS telah menyediakan informasi kepada masyarakat maupun stakeholder mengenai laporan keuangan, visi, misi dan lainnya secara tepat waktu, memadai, jelas, dan akurat. Begitu juga pada LAZNAS telah melakukan keterbukaan informasi pada berbagai pihak, namun masih terdapat beberapa informasi yang belum dicantumkan dalam website LAZNAS seperti mengenai visi, misi, susunan kepengurusan, dan sistem pengawasan pengendalian. Sehingga akan menyulitkan para pihak yang berkepentingan untuk mendapatkan informasi.

Mengenai prinsip Accountability, penerapan pada BAZNAS sudah dilakukan cukup baik dengan ditandai adanya pelaporan keuangan yang disesuaikan dengan standar, namun pada LAZNAS masih terdapat laporan keuangan yang kurang sesuai dengan standar yang ditetapkan, padahal LAZNAS memiliki tugas untuk menyerahkan laporan keuangan pada BAZNAS pusat maupun pemerintah. Pada prinsip Responsibility, BAZNAS dan LAZNAS sudah sama-sama melakukan kesesuaian dalam mengelola organisasi terhadap peraturan perundang-undangan yang berlaku dan melaksanakan tanggung jawab terhadap masyarakat. Dengan diterapkannya prinsip ini maka dapat terpelihara kesinambungan usaha dalam jangka panjang.

Pada prinsip Independency, BAZNAS dan LAZNAS telah dikelola secara profesional tanpa adanya benturan kepentingan dari berbagai pihak. Rata-rata BAZNAS telah melakukan RUPS minimal satu kali dalam satu periode, hal ini sesuai dengan pendapat Malin (2003) bahwa good corporate governance dapat dipandang dari perspektif teori keagenen. Dalam teori agensi dijelaskan bahwa agen diberikan kewenangan untuk mengelola keuangan pihak principal dan harus mampu mempertanggungjawabkan modal tersebut, sehingga dilakukan RUPS agar pihak principal dapat mengendalikan dan mengawasi mengenai modal yang dia berikan. Hal ini dilakukan agar dapat meminimalisir timbulnya ketidakpercayaan pihak principal kepada pihak agen. Namun, dalam hal ini LAZNAS ditemukan masih jarang memberikan informasi mengenai dilakukannya RUPS.

Mengenai prinsip terakhir yaitu Fairness, BAZNAS dan LAZNAS telah melakukan keadilan dan kesetaraan dalam memenuhi hak-hak para pemegang kepentingan dengan memberikan kesempatan kepada seluruh stakeholder dan para muzakki untuk menyampaikan pendapat Berdasarkan hasil uji Mann-whitney test terdapat perbedaan yang signifikan dalam penerapan good corporate governance pada Badan Amil Zakat Nasional dan Lembaga Amil Zakat Nasional di Jawa timur. Hasil ini sesuai dengan hipotesis yang diajukan $\left(\mathrm{H}_{1}\right.$ diterima). Hal ini dapat dilihat pada tabel 1 Badan Amil Zakat Nasional (BAZNAS) memiliki penerapan good corporate governance yang lebih tinggi jika dibandingkan dengan Lembaga Amil Zakat Nasional (LAZNAS). Jumlah rata-rata yang dimiliki Badan Amil Zakat Nasional (BAZNAS) sebesar 13.22, sedangkan Lembaga Amil Zakat Nasional (LAZNAS) memiliki nilai rata-rata yang lebih rendah yaitu sebesar 5.78.

Pada tabel 4 dihasilkan nilai U sebesar 7 dan nilai W sebesar 52. Apabila nilai tersebut dikonversikan ke nilai Z maka besarnya nila Z hitung adalah -2.984. Nilai Asymp. Sig. (2tailed) atau P Value sebesar 0.003, lebih kecil dari 0.05. Artinya terdapat perbedaan yang signifikan dalam penerapan good corporate governance pada Badan Amil Zakat Nasional dan 
Lembaga Amil Zakat Nasional di Jawa Timur. Adanya perbedaan penerapan good corporate governance tersebut disebabkan prinsip-prinsip GCG seperti transparansi, akuntabilitas, pertanggungjawaban, keadilan, dan independen telah diterapkan dengan baik oleh Badan Amil Zakat Nasional dibandingkan pada Lembaga Amil Zakat Nasional.

Semakin tinggi prinsip good corporate governance pada Badan Amil Zakat Nasional maka semakin tinggi pula tingkat kepercayaan masyarakat dan tingkat kepuasan masyarakat terhadap instansi pemerintah. Pentingnya good corporate governance diterapkan dalam organisasi pengelola zakat adalah mampu mengarahkan dan mengendalikan organisasi dalam mencapai keseimbangan maupun tujuan, meningkatkan dan menjaga kepercayaan masyarakat dan stakeholder, sekaligus memberikan keyakinan bahwa zakat yang dikeluarkan para muzakki digunakan secara efektif dan efisien untuk memenuhi kebutuhan terbaik (Husein, 2002).

Hasil tersebut sesuai dengan sebagaimana firman Allah Swt yaitu QS. As-Shaff ayat 4 yaitu sesungguhnya Allah mencintai orang-orang yang berperang di jalanNya dalam barisan yang teratur, mereka seakan-akan seperti suatu bangunan yang kokoh. Selain itu dalam QS. AtTaubah ayat 71 juga disebutkan bahwa orang-orang yang beriman, laki-laki dan perempuan sebagian mereka menjadi penolong bagi sebagian yang lain. Mereka menyuruh untuk berbuat yang makruf dan mencegah dari yang munkar, melaksanakan shalat, menunaikan zakat dan taat kepada Allah akan diberikan rahmat. Hal ini menjadikan organisasi pengelola zakat menjadi tuntutan untuk menjaga amanah stakeholders dengan mematuhi prinsip-prinsip yang ada.

\section{SIMPULAN}

Berdasarkan penelitian tentang penerapan good corporate governance pada Badan Amil Zakat Nasional dan Lembaga Amil Zakat Nasional, dapat dikemukakan beberapa kesimpulan sebagai berikut. Hasil penelitian menunjukkan bahwa Badan Amil Zakat Nasional telah menerapkan prinsip good corporate governance yang meliputi kelima prinsip GCG yaitu Transparancy, Accountability, Responsibility, Independent, dan Fairness. Terbukti bahwa BAZNAS memiliki nilai indeks GCG yang tinggi yaitu sebesar 61,83 artinya BAZNAS mengungkapkan informasi mengenai good corporate governance pada laporan keuangan maupun websitenya dengan nilai yang tinggi. Dengan adanya good corporate governance yang baik, secara tidak langsung dapat meningkatkan kepercayaan dan keyakinan masyarakat bahwa zakat yang mereka bayarkan digunakan secara efisien dan efektif oleh organisasi pengelola zakat.

Sedangkan Lembaga Amil Zakat Nasional juga telah menerapkan prinsip good corporate governance, namun masih belum seutuhnya prinsip-prinsip good corporate governance diterapkan. Dapat dibuktikan bahwaLembaga Amil Zakat Nasional hanya memiliki Corporate Governance Perception Index (CGPI) rata-rata sebesar 44,92. Rendahnya indeks yang dihasilkan karena masih terdapat beberapa informasi yang belum dicantumkan dalam website LAZNAS seperti mengenai visi, misi, susunan kepengurusan, dan sistem pengawasan pengendalian. Sehingga akan menyulitkan para pihak yang berkepentingan untuk mendapatkan informasi.

Berdasarkan hasil uji Mann-whitney test terdapat perbedaan yang signifikan dalam penerapan good corporate governance pada Badan Amil Zakat Nasional dan Lembaga Amil Zakat Nasional. Adanya perbedaan penerapan good corporate governance tersebut disebabkan prinsip-prinsip GCG seperti transparansi, akuntabilitas, pertanggungjawaban, keadilan, dan independen telah diterapkan dengan baik oleh Badan Amil Zakat Nasional dibandingkan pada Lembaga Amil Zakat Nasional. 


\section{Keterbatasan Penelitian}

Keterbatasan penelitian ini hanya dilakukan pada wilayah Jawa Timur, sehingga sampel pada penelitian ini masih terlalu sedikit. Selanjutnya pada saat melakukan content analys terdapat beberapa website badan atau lembaga organisasi pengelola zakat yang tidak dapat diakses sehingga harus mengganti dengan lembaga lain yang dapat diakses.

\section{Saran}

Penelitian selanjutnya diharapkan dapat memperluas cakupan objek penelitian pada skala organisasi pengelola zakat yang lebih luas sehingga memperoleh hasil yang lebih maksimal. Peneliti selanjutnya dapat dilakukan komparasi pada aspek lain berdasarkan karakteristik organisasi pengelola zakat yang ada. Selanjutnya bagi masyarakat diharapkan agar dapat meningkatkan kesadaran terhadap pentingnya membayar zakat guna mensejahterakan masyarakat kalangan bawah sehingga perekonomian Indonesia meningkat. Kemudian bagi organisasi pengelola zakat, diharapkan untuk meningkatkan dan mempertahankan prinsip good corporate governance atau tata kelola sehingga terciptanya organisasi pengelola zakat yang amanah, dapat dipercaya dan profesional.

\section{DAFTAR PUSTAKA}

Anwar, Hidayat. (2012). Model Tatakelola Badan Dan Lembaga Amil Zakat Sebagai Upaya Untuk Meningkatkan Pemberdayaan Ekonomi Masyarakat (Studi Pada Badan/Lembaga Amil Zakat Di Kota Malang. Jurnal Humanity,(7)2,1 - 13.

BUMN, K. N. 2011. Per-01/MBU/2011 tentang Penerapan Tata Kelola Perusahaan Yang Baik (Good Corporate Governance) Pada Badan Usaha Milik Negara.

Deegan.(2002). Introduction: The Legitimizing Effect Of Social And Environmental Disclosure - A Theoretical Foundation. Accounting, Auditing \& Accountability Journal, (15),3, 282-311.

Eisenhardt, K. M., (1989). Agency Theory: An Assessment and Review. Academy of Management Review. (14), 1, 57-74.

Eri, S. (2008). Manajemen Zakat Ciputat, Jakarta: Institut Manajemen Zakat (IMZ).

Forum for Corporate Governance in Indonesia (FCGI).

Ghozali, I. (2006). Statistik non-parametrik: Teori dan aplikasi dengan program SPSS. Semarang: Universitas Diponegoro.

Hery. (2010). Potret Profesi Audit Internal. Bandung.

Husein, Fakhri. (2002). Menata Ulang Sistem Zakat. Jakarta: PT. Rajawali Press. hlm: 52.

Holsti, O. R. 1969. Content Analysis for the Social Sciences and Humanities. Reading, MA: Addison-Wesley.

Jansen, M., dan William Meckling. (1976). A Theory of the Firm: Governance, Residual Claims and Organizational Forms. Journal of Financial Economics. (3)4.

Kiryanto, dan V. N. Khasanah. (2013). Analisis Karakteristik Muzakki Dan Tata Kelola Laz Terhadap Motivasi Membayar Zakat Penghasilan. Jurnal Akuntansi Indonesia, (2)1.

Komite Nasional Kebijakan Corporate Governance (KNKCG).

Nasution, Mustafa Edwin. 2009. Current issue lembaga Keuangan Syariah. Jakarta: Kencana Prenada Media Group.

Ross, Stephen. (1973). The Economic Theory of Agency: The Principal's Problem. American Economic Review. (63) 2, 134-139. 
Setia, Hamid. (2018). Kajian Bisnis Sekolah Tinggi Ilmu Ekonomi Widya Wiwaha.(26)21.

Sjahputra, I., dan A. W. Tunggal. 2010. Internal Audit and Corporate Governance.Harvarindo. Sugiyono. 2009. Metode Penelitian Bisnis (Pendekatan Kuantitatif, Kualitatif, dan R\&D). Bandung: Alfabeta.

Syakhroza, A. (2003). Theory of Good Corporate Governance.No. 8, 9-25.

Tan, H.P., D. Plowman, P.Hancock. (2003). Intellectual Capital and Financial Retuns of Companies. Journal of Intellectual Capital.(8)1, 76-95.

Ulum, I., dan A. Juanda. 2016. Metodologi Penelitian Akuntansi. Yogyakarta: Aditya Media Publishing.

Ulya, Z. (2015).Pengelolaan Zakat Sebagai Bentuk Penegakan Ham Dalam Meningkatkan Kesejahteraan Rakyat. $A L$ - 'ADALAH, (12) 3.

Undang Undang 1945 Pasal 33. Pengertian Perekonomian, Pemanfaatan SDA, dan Prinsip Perekonomian Nasional.

Undang Undang Republik Indonesia Nomor 23 Tahun 2011. Pengelolaan Zakat.

Undang Undang Republik Indonesia Nomor 38 Tahun 1999. Pengelolaan Zakat.

Warsono, S.. F. Amalia, and D. K. Rahajeng, 2009. Corporate Governance Concept and Model: Preserving True Organization Welfare. Yogyakarta: Center for Good Corporate Governance Universitas Gadjah Mada. 